\title{
Evaluation of Physico-Chemical Parameters of Stream Water and Their Cytotoxic Effects on Allium Cepa Around Ibobo Coalmine, Kogi State, Nigeria
}

\author{
Tope Alege* \\ Department of Earth Sciences, Kogi State University, P.O Box 347, Lokoja, Kogi State, Nigeria \\ Yomi Gideon \\ Department of Earth Sciences, Kogi State University, Anyigba, Nigeria \\ Gbenga Alege \\ Department of Biological Sciences, Federal University of Lokoja, Kogi State, Nigeria
}

\begin{abstract}
The Ibobo coal mine is an abandoned mine located in the middle belt of Nigeria and lies in the Ajali Formation within the Anambra Basin. The adjoining rivers and streams in this community serve as sources of water for human consumption and plant use. The study was conducted in January 2016 at the peak of the dry season. Major and trace elements were measured in the water samples collected and subjected to the following analysis; conductometry and electro-analytical techniques for physical parameters; titrimetry and spectrophotometry for anions; and flame atomic absorption spectrophotometry for the cations. Further study was carried out to evaluate the cytotoxic effects of the water samples from plants and other living organisms using the root meristems of Allium cepa (onion). This study revealed that the average concentrations of Iron $(0.344 \mathrm{mg} / \mathrm{L})$, Lead $(0.024 \mathrm{mg} / \mathrm{L})$ and Cadmium $(0.004 \mathrm{mg} / \mathrm{L})$ are higher than the maximum permissible limits of Standard Organisation of Nigeria (SON) and World Health Organisation (WHO) guidelines for domestic and drinking water qualities. Water from the streams should, therefore, be discouraged for both domestic and agricultural purposes through public health awareness program.
\end{abstract}

Keywords: Physico-chemical analysis, spectrophotometry, TDS, Allium cepa, Mamu Formation, Cytotoxic DOI: $10.7176 / \mathrm{JEES} / 9-6-07$

Publication date:June $30^{\text {th }} 2019$

\section{Introduction}

The role of water in living things is significant. It cuts across all sphere of living things such as human consumption, as well as plant and animal life. The effect of mining activities in rural areas has led to the degradation of their water sources (Awalla, (2013).

The Ibobo community which is the focal locality of the study area is located on longitude $7^{\circ} 57^{\prime} 22.53^{\prime \prime}$ E and latitude $7^{\circ} 33^{\prime} 6.75^{\prime \prime} \mathrm{N}$. It is situated within Mamu Formation of Anambra sedimentary basin in Central Nigeria (fig. 1). Ibobo stream 1 and 2 adjoined to flow downward over unmined coal towards Emewe Efokpa and subsequently joined by Adiele stream (fig. 2). This study aims at evaluating the physicochemical parameters of surface water around the abandoned coal mine and examining its effects on plants genetic system using Allium серa as the test organism. 




Scale 1:750,000

Fig. 1: Geological map of the study area (modified after the Nigerian Geological Survey Agency, 2006)

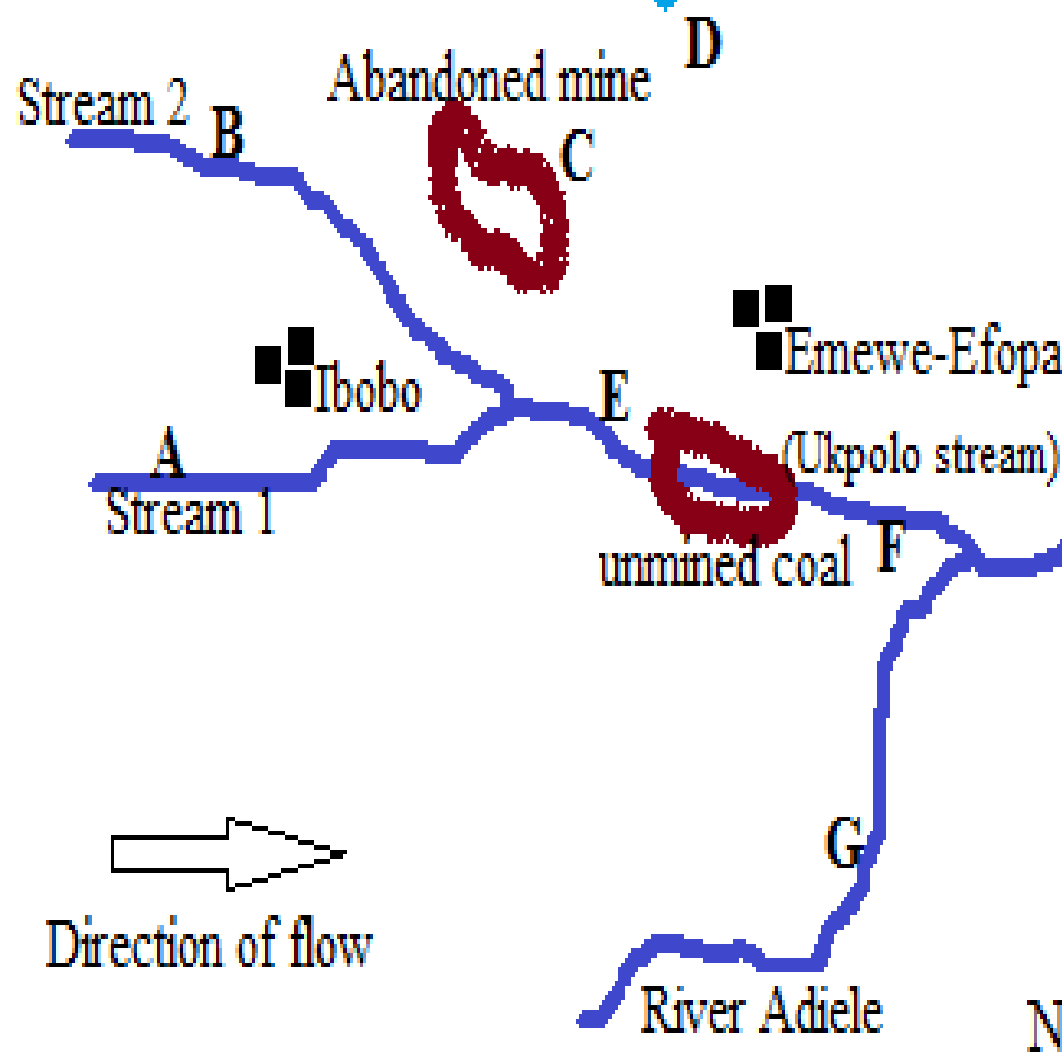

Not drawn to scale

Fig. 2: Schematic diagram of the stream network

\subsection{Materials and Methods}

Materials used include:

i. New one-litre plastic water container 




\subsection{Methods of Water Analysis}

Sensitive parameters such as $\mathrm{pH}$, temperature, electrical conductivity and total dissolved solids of the water samples were measured on the field. Seven water samples A, B, C, D, E, F, and G were taken from Ibobo stream 1, stream 2, mine water, spring water just above the coal mine, Ukpolo upstream and downstream at Emewe Efokpa as well as River Adiele respectively. Major and trace elements were measured in the water samples collected and subjected to the following analysis; conductometry and electro-analytical techniques for physical parameters; titrimetry and spectrophotometry for anions; and flame atomic absorption spectrophotometry for the cations. Conductometry and electro-analytical techniques methods were used for physical parameters measurement while titrimetric, and spectrophotometry methods were employed for concentrations of anionic and cationic determinations, respectively.

\subsection{Methods of Cytotoxic Analysis}

Further study was carried out to evaluate the cytotoxic effects of the water samples A-D on plants and other living organisms using the root meristems of Allium cepa (onion) as a case study. The root tips were grown in different concentrations of the water samples while purified water was used as a control. Root tips of onions grown in the water and control samples and were harvested between 7.30am and 8.30am for cytological studies. Pretreatment, fixation, hydrolysis, squashing and staining was done according to the method highlighted by Akinyele (2007). Normal mitotic stages and aberrant cells were snapped using photomicrograph at X40 objectives. Ten counts each were taken from ten different slides from each concentration.

\subsection{Results}

\subsection{Temperature and $\mathrm{pH}$ of Water}

The temperature of the water samples collected at the time of collection is on an average of $30.68^{\circ} \mathrm{c}$, while the $\mathrm{PH}$ values of the water samples around the mine exhibited an average acidity value of 5.66.

\subsection{Electrical Conductivity (EC) and Total Dissolved Solids (TDS)}

Lowest electrical conductivity (EC) and total dissolved solids (TDS) values of $0.00 \mu \mathrm{s} / \mathrm{cm}$ and $8 \mathrm{mg} / \mathrm{L}$ respectively were recorded at Ibobo stream-1 while Ukpolo upstream indicates the highest values at $0.33 \mu \mathrm{s} / \mathrm{cm}$ and $237 \mathrm{mg} / \mathrm{L}$ respectively (Table 1). Concentrations of EC and TDS in River Ukpolo upstream which flows directly over the un-mined coal increases downstream from $0.09 \mu \mathrm{s} / \mathrm{cm}$ and $73 \mathrm{mg} / \mathrm{L}$ into $0.33 \mu \mathrm{s} / \mathrm{cm}$ and $237 \mathrm{mg} / \mathrm{L}$ respectively. This is an indication of some level of pollution within the water.

\subsection{Chemical Concentrations}

Averagely, cationic concentrations of water samples around the area shows $\mathrm{Ca}^{2+}>\mathrm{Na}^{2+}>\mathrm{K}^{+}>\mathrm{Mg}$, while the anionic component is in the order of $\mathrm{So}_{4}{ }^{2-}>\mathrm{No}_{3}{ }^{-}>\mathrm{Cl}$ (fig. 3 and 4).

\subsection{Cytological Parameters}

The chromosomal aberrations associated with the stream samples are C-mitosis, binucleate cells, sticky chromosomes and vacuolated cells (fig. 5). The highest aberrant cells (4) was recorded in Ibobo spring (fig. 5). Only C-mitosis was recorded in sample A1 while sample D4 showed all the four mutagenic condition recorded in this study. Analysis of variance (ANOVA) result (Table 2) revealed that five out of the ten cytological parameters considered revealed differences across water samples examined in the study. 


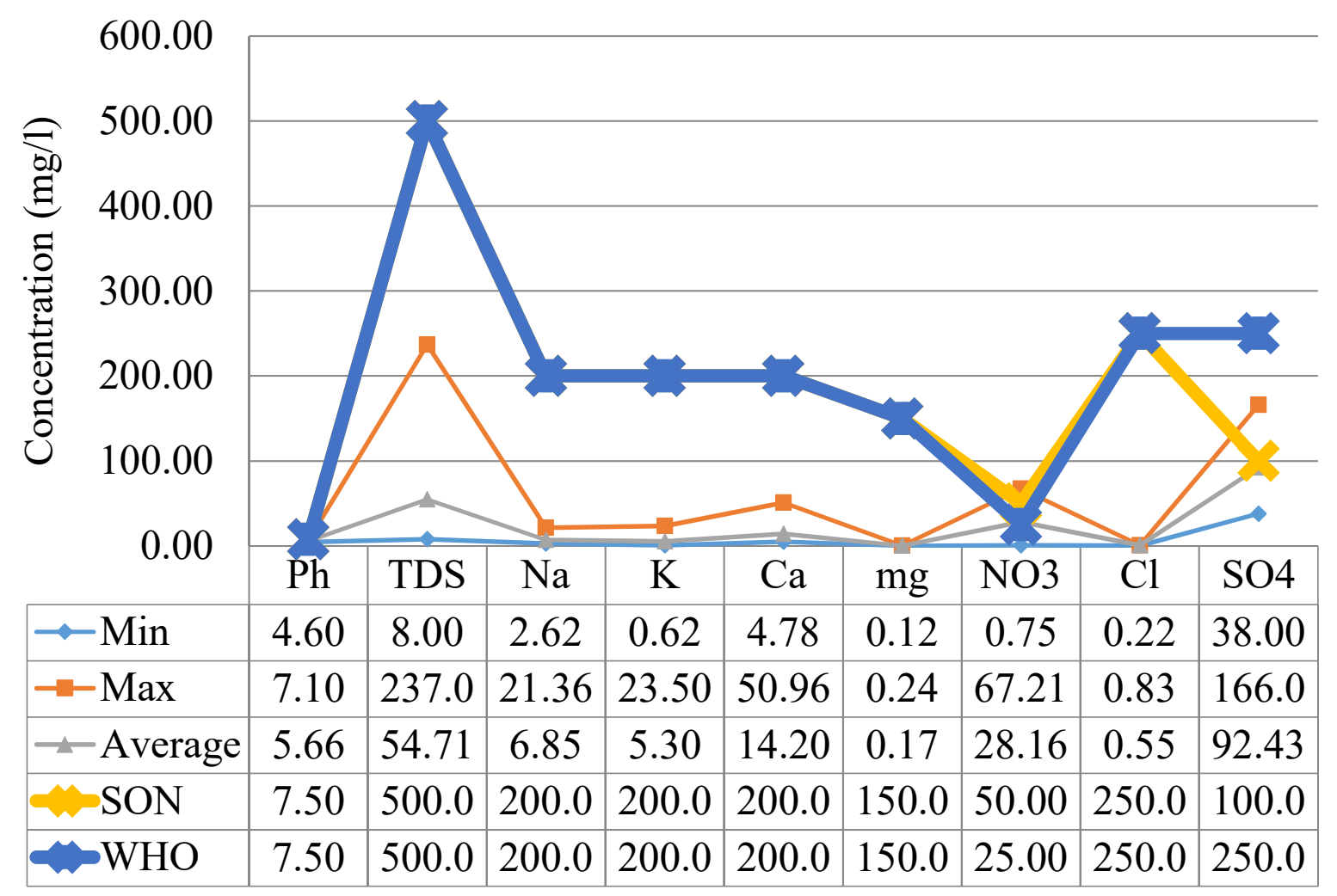

Fig. 3: Chart showing concentrations of water parameters compared with standards



Fig. 4: Chart showing concentrations of water parameters compared with standards 

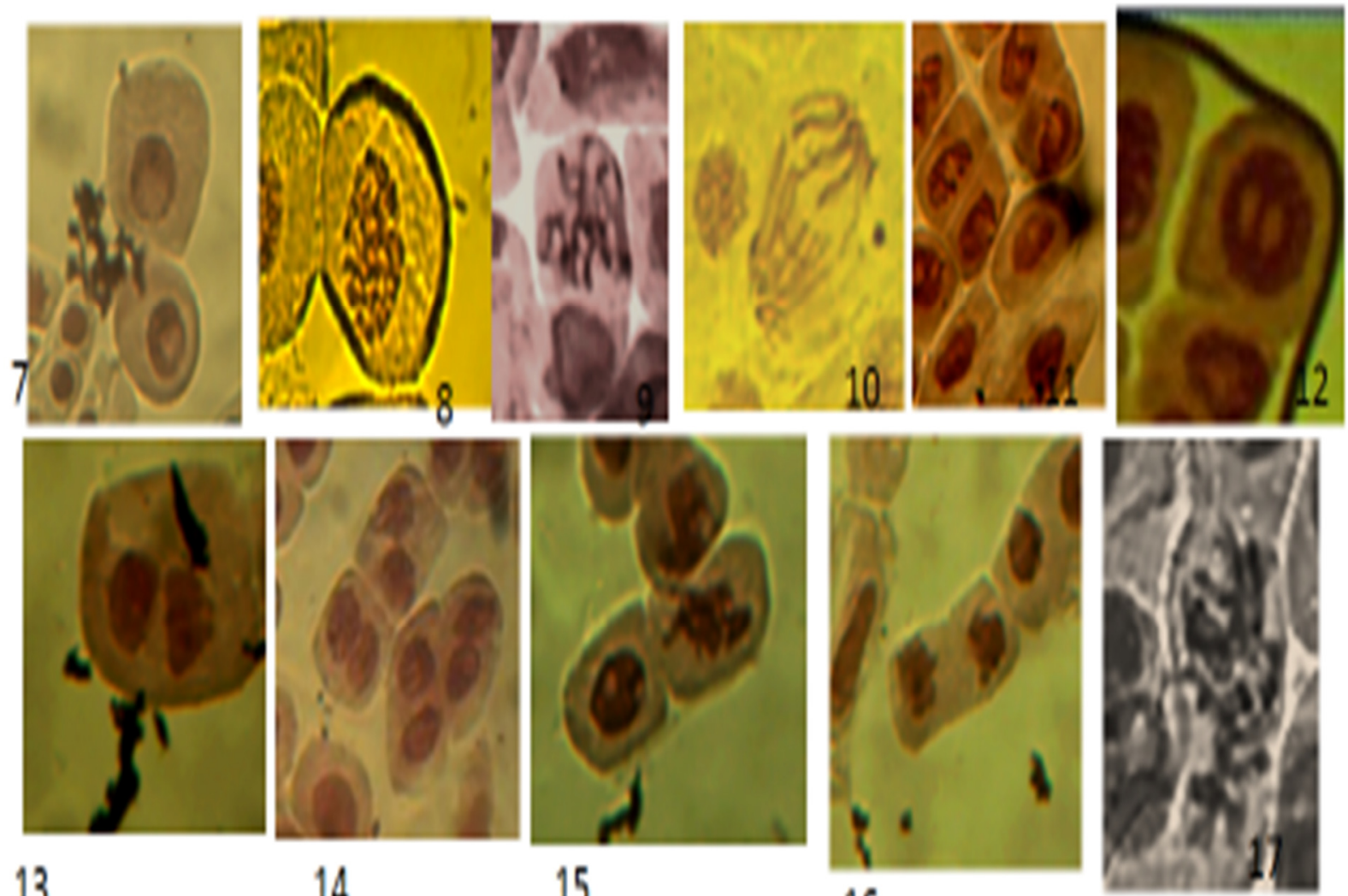

13

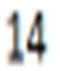

15

16

Fig. 5: Photographs of Allium cepa root tip cells showing normal stages of mitotic division and aberrant cells from treated root tips (7) Normal interphase cell (8) Normal prophase cell, (9) normal metaphase, (10) normal anaphase, (11) normal telophase, (12) vacuolated cell, (13) binucleate cells (14) binucleate cells (15) sticky chromosome (16) sticky chromosome (17) C-mitosis, (Magnification $\times 400$ ).

Table 2: Effect of the studied water samples on the cytological parameter of Onion mitosis

\begin{tabular}{|c|c|c|c|c|c|c|c|c|c|c|}
\hline $\begin{array}{l}\text { Water } \\
\text { Sample } \\
\text { s }\end{array}$ & $\begin{array}{l}\text { Total } \\
\text { No of } \\
\text { cell }\end{array}$ & $\begin{array}{l}\text { No of } \\
\text { interpha } \\
\text { se }\end{array}$ & $\begin{array}{l}\text { No of } \\
\text { prophas } \\
\text { e }\end{array}$ & $\begin{array}{l}\text { No. of } \\
\text { metapha } \\
\text { se }\end{array}$ & $\begin{array}{l}\text { No of } \\
\text { anaphas } \\
\text { e }\end{array}$ & $\begin{array}{l}\text { No of } \\
\text { telophas } \\
\text { e }\end{array}$ & $\begin{array}{l}\text { No of } \\
\text { binuclea } \\
\text { te cells }\end{array}$ & $\begin{array}{l}\text { No of } \\
\text { C- } \\
\text { mitosi } \\
\text { s }\end{array}$ & $\begin{array}{l}\text { No of } \\
\text { vacuolate } \\
\text { d cells }\end{array}$ & $\begin{array}{l}\text { No of sticky } \\
\text { chromosom } \\
\text { es }\end{array}$ \\
\hline A1 & $\begin{array}{l}102.6 \\
0\end{array}$ & 71.20 & 10.60 & 12.70 & 3.60 & $3.10^{\mathrm{b}}$ & $0.00^{\mathrm{a}}$ & $1.10^{\mathrm{b}}$ & $0.00^{\mathrm{a}}$ & $0.00^{\mathrm{a}}$ \\
\hline B2 & 94.70 & 64.40 & 9.40 & 13.70 & 2.90 & $1.30^{\mathrm{a}}$ & $2.20^{\mathrm{c}}$ & $0.80^{b}$ & $0.00^{\mathrm{a}}$ & $0.00^{\mathrm{a}}$ \\
\hline C3 & $\begin{array}{l}107.2 \\
0\end{array}$ & 72.30 & 9.30 & 12.30 & 2.80 & $1.90^{\mathrm{a}}$ & $3.50^{\mathrm{d}}$ & $2.70^{c}$ & $0.00^{\mathrm{a}}$ & $2.30^{\mathrm{c}}$ \\
\hline D4 & $\begin{array}{l}118.6 \\
0\end{array}$ & 73.00 & 8.60 & 13.40 & 3.20 & $5.30^{\mathrm{c}}$ & $4.10^{\mathrm{e}}$ & $2.30^{\mathrm{c}}$ & $5.20^{\mathrm{c}}$ & $3.50^{\mathrm{d}}$ \\
\hline G3 & $\begin{array}{l}102.1 \\
0\end{array}$ & 69.60 & 9.70 & 12.50 & 3.30 & $2.60^{\mathrm{b}}$ & $1.60^{\mathrm{b}}$ & $1.60^{\mathrm{bc}}$ & $0.00^{\mathrm{a}}$ & $1.20^{\mathrm{b}}$ \\
\hline $\begin{array}{l}\text { Contro } \\
1(\mathrm{~F})\end{array}$ & $\begin{array}{l}108.6 \\
0\end{array}$ & 79.60 & 10.30 & 13.30 & 3.50 & $1.80^{\mathrm{a}}$ & $0.00^{\mathrm{a}}$ & $0.00^{\mathrm{a}}$ & $0.00^{\mathrm{a}}$ & $0.00^{\mathrm{a}}$ \\
\hline $\begin{array}{l}\text { LSD } \\
\text { Value }\end{array}$ & NS & NS & NS & NS & NS & 0.63 & 0.23 & 0.56 & 0.46 & 0.50 \\
\hline
\end{tabular}

\subsection{Discussion}

The findings indicate that water from these streams (especially stream D) have high mutagenic content. The average concentrations of $\operatorname{Iron}(0.344 \mathrm{mg} / \mathrm{L}), \operatorname{Lead}(0.024 \mathrm{mg} / \mathrm{L})$ and Cadmium $(0.004 \mathrm{mg} / \mathrm{L})$ are higher than the maximum permissible limits of Standard Organisation of Nigeria(SON) and World Health Organisation(WHO) guidelines for domestic and drinking water qualities (figs. 3 and 4). The presence of anions and higher concentrations of $\mathrm{Fe}, \mathrm{Pb}$, and $\mathrm{Cd}$ in the water samples gives a clear indication of the dissolution of harmful 
substances due to coal mining activities (Edet, 2004).

The presence of binucleate cell, C-mitosis, vacuolated cells, and sticky chromosomes indicates that the water samples are mutagenic and are not safe for consumption. Only C-mitosis was recorded in sample A1 which indicates that water at that location is safer for consumption than any other location. In contrary, D4 water presents a greater risk to human health because of its high mutagenic rate.

Thus, the heavy metal pollution in the water is recognized as primary environmental contaminants causing cytotoxic, mutagenic and cancerous (carcinogenic) effects which influence the quality of crops according to Alege (2014) and Edet (2002). This will, in turn, have profound consequences for the health as well as the life of animals and human beings in these local communities by way of the food chain.

\subsection{Conclusions and Recommendation}

The exposed coal and its mining activities around the study area have increased the concentrations of lead, cadmium, nickel, sulphate, and nitrate above SON and WHO water quality standards for consumption, thereby increasing the mutagenic level of the water samples. Consequently, this will adversely affect the lives of plants, animals and human beings directly by consumption and indirectly through the food chain (Nganje, 2010).

Water from the streams should be discouraged for domestic and agricultural purposes through public health awareness program. Safe potable water should be provided as an alternative for the communities within the catchment area of the streams. A documentary program showcasing the current challenges of potable water and its attendant health implication in these communities is highly recommended.

\section{References}

Akinyele B.O (2007). African Journal of Biotechnology, Vol. 6:2585 - 2589.

Alege G. O. and Ojomah B. O., (2014). Cytotoxic effects of Aloe vera leaf extract on Allium sativum root tips. European Journal of Experimental Biology, 4(4):9-14.

Awalla, C. O. C., (2013). An appraisal of the water-related contaminants as they affect the environment around the Enugu coal mines of Enugu state, southeastern Nigeria. International Journal of Physical Sciences, vol. 8(44), pp.2023-2028.

Edet A.E., Offiong O.E., (2002). Evaluation of water quality pollution indices for heavy metal contamination monitoring. A case study from Akpabouyo - Odukpani area, lower Cross River Basin (Southeastern Nigeria). Geol. J. 40: $1-10$.

Edet A.E., Merkrel B.J, Offiong O.E., (2004). Contamination risk assessment of fresh groundwater using the distribution and chemical speciation of some potentially toxic elements in Calabar (Southeastern Nigeria). Environ Geol. 45: 1025 -1035.

Nganje, T. N., Adamu, C. I., Ntekim, E. E. U., Ugbaja, A. N., Neji, P., and Nfor, E. N. (2010).Influence of mine drainage on water quality along River Nyaba in Enugu South-Eastern Nigeria. African Journal of Environmental Science and Technology Vol. 4(3), pp. 132-144. 